\title{
Al'Ad̂̂lah \\ PERSEPSI TOKOH LINTAS AGAMA KABUPATEN PROBOLINGGO TERHADAP PERPPU UU NOMOR 2 TAHUN 2017 TENTANG HAK BERSERIKAT
}

\author{
M. Saiful Anam \\ Institut Agama Islam Negeri Jember \\ Muhammadsaifulanam12@gmail.com \\ Abd. Rozaq \\ Institut Agama Islam Negeri Jember \\ rahmanzacky1981@gmail.com
}

\begin{abstract}
Rights are the power to accept or do something that should be accepted or carried out by certain parties and can be prosecuted forcibly. There are two basic types of human rights, equality rights such as the right to be treated equally and the right to freedom such as freedom to worship, freedom to hold opinions, freedom of association, ect. Many pro-contro in society toward Government Regulation Act No. 2 of 2017 on the right of association. Suspicion from some communities that the motives or intentions of the Act are actually more aimed at Islamic-based community organizations than others. This applied research type is a form of descriptive research that describes a review of problems in society. In this study the researchers reviewed the opinions of interfaith leaders on the right to organize in A ct No. 2 of 2017. The results of this study are: 1) the perception of the Islamic community leaders in Probolinggo district, is to support the changes of the act of community organizations. This is due to several legal reasons related to the emergency conditions that occurred. In addition, the right to organize in Islam needs to be regulated. God regulates and gives a measure of the right to associate. Not absolutely free. 2) Whereas according to Christian leaders, associate rights are social rights. Social rights are useful for maintaining and facilitating the achievement of personal rights. So the association right is free to use if it is not in its orientation, namely ensuring the fulfillment of personal rights such as speaking, living happily, ect. So automatically the right of association should not be fought, if it is contrary with personal rights. This has become the basis for an agreement with Act No. 2 of 2017 agreed to be formalized.
\end{abstract}

Keywords: Figures Perception, Act No. 2 of 2017

\section{Pendahuluan}

Hak adalah kuasa untuk menerima atau melakukan suatu yang semestinya diterima atau dilakukan melulu oleh pihak tertentu dan tidak dapat oleh pihak manapun juga 
yang pada prinsipnya dapat dituntut secara paksa olehnya. Hak asasi manusia mencakup dua jenis yang mendasar/fundamental yaitu, hak persamaan seperti hak untuk diperlakukan sama dan hak kebebasan seperti kebebasan untuk beribadah, kebebasan untuk menyampaikan pendapat, kebebasan berserikat dan sebagainya.

Pancasila dan UUD 1945 pada hakikatnya secara filosofis, sosiologis, maupun yuridis menjamin hak berserikat dan berkumpul sebagai hak dasar/asasi warga Negara yang harus dihormati, diakui, dilindungi, dan dipenuhi oleh Negara. Ketika warga negara membentuk organisasi yang bertujuan untuk meningkatkan kualitas hidup dan kehidupannya guna mewujudkan kebahagiaan dunia dan akhirat, maka Negara tidak berhak untuk menghalanginya dengan cara apapun. Hal ini sesuai dengan amanat Pasal 1 ayat (2) UUD 1945 yang mengatur bahwa Kedaulatan adalah ditangan Rakyat, Pasal 1 ayat (3) UUD 1945 yang mengatur bahwa Indosesia adalah Negara Hukum, dan Pasal 28 UUD 1945 yang mengatur bahwa setiap warga negara berhak untuk berserikat dan berkumpul sebagai perwujudan dari hak-hak asasi manusia (HAM).

Salah satu HAM yang dijamin oleh UUD Negara RI 1945 ialah kebebasan yang diatur dalam Pasal 28 E ayat (3) yang menyatakan : "Setiap orang berhak atas kebebasan berserikat, berkumpul dan mengeluarkan pendapat". Meskipun dalam perubahan UUD Negara RI 1945 tidak menyentuh Pasal 28, tetapi mengadopsi norma baru dalam Pasal 28E ayat (3), karena Pasal 28 dianggap tidak mengandung jaminan HAM yang seharusnya menjadi muatan konstitusi negara demokrasi. Oleh karena itu, pemuatan kembali hak berserikat, berkumpul dan mengeluarkan pendapat dalam Pasal 28E ayat (3) UUD Negara RI 1945, adalah untuk menegaskannya sebagai salah satu HAM yang menjadi hak konstitusi, dan yang menjadi kewajiban negara terutama pemerintah untuk melindungi, menghormati, memajukan dan memenuhinya. ${ }^{2}$

Sejalan dengan itu kemudian dalam Pasal 24 ayat (2) Undang-Undang Nomor 39 Tahun 1999 tentang Hak Asasi Manusia, yang selanjutnya disebut UU HAM menyatakan: "Setiap warga negara atau kelompok masyarakat berhak mendirikan Partai Politik, Lembaga Swadaya Masyarakat atau organisasi lainnya untuk berperan serta dalam jalannya pemerintahan dan penyelenggaraan negara sejalan dengan tuntunan perlindungan, penegakan dan pemajuan bak asasi manusia sesuai dengan ketentuan perundang-undangan"."

Setelah melihat pengaturan atas HAM yang telah dijamin dalam UUD Negara RI 1945 serta Undang-undang HAM itu, seharusnya tidak perlu lagi dibuat pengaturan oleh undang-undang untuk memastikan adanya kemerdekaan atau kebebasan bagi setiap orang untuk berorganisasi dalam wilayah Indonesia. Hanya saja pemerintah dalam hal pembentukan UU Ormas hanya perlu mengatur secara spesifik bagaimana cara Organisasi Kemasyarakatan dalam menggunakan dan mengimplementasikan kebebasan

\footnotetext{
${ }^{1}$ Sekertaris Negara, Undang-Undang Dasar Negara Republik Indonesia Tahun 1945

${ }^{2}$ Jimly Asshidiqie, Kemerdekaan Berserikat, Pembubaran Partai Politik dan Mabkamah Konstitusi, Sekretariat Jenderal dan Kepaniteraan Mabkamah konstitusi, (Jakarta:Konstitusi Pers, 2005) 29

3 Sekertaris Negara, Undang-Undang Dasar Negara Republik Indonesia Nomor 39 Tahun 1999 tentang Hak Asasi Manusia
} 
itu, dan menjelaskan syarat-syarat dan prosedur pembentukan, pembinaan, penyelenggaraan kegiatan, pengawasan, dan pembubaran organisasi lebih rinci, yaitu dengan undang-undang beserta peraturan pelaksanaannya.

Karena alasan itulah, pemerintah memandang perlu untuk menyusun satu undang-undang berdasarkan ketentuan UUD Negara RI 1945 sebelum reformasi, yaitu UU No. 8 Tahun 1985 tentang Organisasi Kemasyarakatan. Setiap orang diberi hak untuk bebas membentuk atau ikut serta dalam keanggotaan atau pun menjadi pengurus organisasi dalam kehidupan bermasyarakat dalam wilayah Indonesia. ${ }^{4}$

Dalam hal ini, seharusnya Negara wajib menghormati dan melindungi organisasi masyarakat tersebut. Sebagai salah satu perwujudan dari tanggung jawab Negara dalam pemberian jaminan pengakuan, penghormatan, perlindungan, dan pemenuhan bagi hak warga Negara untuk membentuk dan menjalankan organisasi kemasyarakatan (Ormas) tersebut adalah dengan membentuk Undang-Undang No. 17 tahun 2013 tentang Organsiasi Kemasyarakatan.

Pada sisi lainnya, merujuk kepada Pasal 22 ayat (1) UUD 1945 yang menyatakan bahwa "Dalam hal ihwal kegentingan yang memaksa, Presiden berhak menetapkan peraturan pemerintah sebagai pengganti undang-undang". ${ }^{5}$ Dalam ketentuan ini pada dasarnya memberikan dasar hukum bagi kewenangan Presiden untuk membentuk peraturan perundangundangan setingkat undang-undang dalam upaya menangani dan menyelesaikan terhadap keadaan darurat negara dan pemerintahan yang berada pada situasi bahaya atau genting. Keadaan tersebut berdasarkan hasil kajian dan pertimbangan yang rasional dan normatif yang menunjukkan secara faktual telah sungguh-sungguh (terstruktur dan terukur) mengancam keselamatan negara, jika pemerintah tidak cepat mengambil tindakan hukum konkret.

Unsur "kegentingan yang memaksa" harus menunjukkan dua ciri umum, yaitu: (1) Ada krisis (crisis), dan (2) Kemendesakan (emergency). Suatu keadaan krisis apabila terdapat gangguan yang menimbulkan kegentingan dan bersifat mendadak (a grave and sudden disturbunse).Kemendesakan (emergency), apabila terjadi berbagai keadaan yang tidak diperhitungkan sebelumnya dan menuntut suatu tindakan segera tanpa menunggu permusyawaratan terlebih dahulu. Atau telah ada tanda-tanda permulaan yang nyata dan menurut nalar yang wajar (reasonableness) apabila tidak diatur segera akan menimbulkan gangguan baik bagi masyarakat maupun terhadap jalannya pemerintahan.

Apabila syarat tersebut telah terpenuhi, dengan sendirinya Presiden selaku penanggung jawab tertinggi dalam penyelenggaraan pemerintahan dengan kewenangan konstitusional yang dimilikinya untuk mengatur hal-hal yang diperlukan dalam rangka menjalankan fungsi-fungsi penyelenggaraan negara dan roda pemerintahan yang dipimpinnya dengan menerbitkan Peraturan Pemerintah Pengganti Undang-Undang (Perppu).

${ }^{4}$ Jimly Asshiddiqie, Mengatur Kebebasan Berserikat Dalam Undang-Undang, http://jimlyschool.com/ read/analisis/274/ mengatur-kebebasanberserikat-dalam undangundangterakhir diakses tanggal 12-05-2017.

${ }^{5}$ Sekertaris Negara, Pasal 22 ayat (1) Undang-Undang Dasar 1945. 
Salah satu contoh Perppu yang dikeluarkan oleh pememerintah pada era keperintahan Jokowi Widodo adalah Perppu No.2 tahun 2017 tentang Organsiasi Kemasyarakatan.Pada dasarnya Perppu yang mengatur perihal pembubaran organisasi kemasyarakatan (ormas) yang diduga melanggar hukum ini sudah relative baik, apabila diukur dari prinsip Negara Hukum dan Negara Demokrasi yang menghormati Hak Asasi Manusia yang dianut oleh UUD 1945 sudah relatif baik dan memadai. Aturan tersebut terbilang sudah cukup lengkap karena menjelaskan tentang bagaimana tata cara dan prosedur pembubaran ormas, dengan melalui proses dan tahapan yang lebih mengedepankan cara-cara yang persuasif, demokratis, dan menegakkan due process of law dengan melibatkan lembaga peradilan.Akan tetapi, mencermati dengan seksama terbitnya Perppu itu, dalam konteks kehidupan bernegara dan bermasyarakat dewasa ini, telah begitu banyak memunculkan pertanyaan publik dan cenderung menolak.

Pertanyaan-pertanyaan tersebut antara lain, ditinjau dari aspek fakta empiris (empirical evidance) maupun fakta yuridis (legal evidance), apakah sudah memenuhi persyaratan prosedural maupun substansial sebagimana diuraikan di atas? Apakah pemerintah sudah memiliki kriteria, ukuran yang objektif, rasional, dan normatif dalam melakukan penilaian terhadap ormas yang membahayakan Negara, sehingga sudah dianggap diperlukan "jalan pintas" dengan menerbitkan Perppu tersebut? Apakah memang sudah ada bukti yang sangat kuat dan meyakinkan secara objektif dan rasional bahwa ada ormas yang telah sungguh-sungguh melakukan suatu gerakan atau tindakan yang terstruktur, sistematis dan masif mengarah pada ancaman bagi kehidupan kenegaraan dan kemasyarakatan? Adakah data, informasi, keterangan, bahan, bukti, dan ukuran yang dapat dipelajari dan dipahami oleh masyarakat terhadap hasil kajian dan penilaian Pemerintah bahwa adanya ormas yang telah berpotensi mengancam kehidupan kenegaraan dan kemasyarakatan, sehingga pemerintah tidak dituduh otoriterian?.

Terjadi banyak pro-kontro dalam masyarakat terkait terbitnya aturan tersebut. Kecurigaan dan dugaan kuat dari sebagian masyarakat dan pengamat bahwa motif atau intensi terbitnya Perppu No. 2 tahun 2017 itu sesungguhnya lebih ditujukan kepada ormas yang berbasis Islam ketimbang ormas lainnya. Mengapa kesan dan dugaan ini muncul, karena beberapa indikator yakni, yang pertama, bahwa akhir-akhir ini Pemerintah sangat intens mengancam ormas-ormas berbasis Islam (antara lain HTI dan FPI) untuk dibubarkan dengan dalih telah melakukan pelanggaran hukum. Untuk hal ini Menkopolhukham Wiranto dan Menteri Hukum dan HAM (Menkumham) Yasonna Hamonangan Laoly pernah menyatakan Pemerintah akan menempuh jalur sesuai hukum (melalui permohonan ke PN sebagaiman diatur dalam UU No. 17 Tahun 2013). Kedua, Dalam konteks kehidupan keberagamaan (religiositas), ada fakta akhir-akhir ini yang tak terbantahkan bahwa Pemerintah dan oknum aparatur penegak hukum banyak berseteru (kurang harmonis) dengan sebagian tokoh, ormas, kelompok, dan umat Islam. Dengan terbitnya Perppu ini mempertunjukkan kondisi dan sistuasi yang dieskalasi dan dimatangkan untuk lebih menekan gerakan Umat Islam yang cenderung sangat kritis kepada kebijakan dan tindakan Pemerintah yang merugikan Umat Islam. Sehing- 
ga dengan Perpu inilah dijadikan dasar pembenar secara yuridis untuk melakukan tindakan yang lebih represif kepada ormas Islam. Ketiga, mengapa Perppu ini lebih ditujukan kepada ormas Islam daripada ormas lainnya yang menjadi target pembubaran, karena sesungguhnya membubarkan organisasi yang berafiliasi pada faham komunisme (yang dilakukan oleh tokoh dan aktivis PKI yang akhir-akhir ini marak dengan berbagai tampilannya), tidak perlu payung hukum lagi karena sesungguhnya sudah sangat jelas ada dasar hukumnya. Misalnya Ketetapan MPRS No.XXV/MPRS/1966 tentang Pembubaran PKI, Pernyataan sebagai Orgnaisasi Terlarang di seluruh Wilayah NKRI yang sudah amat lengkap untuk dijalankan. Demikian pula Perppu ini tidak dimaksudkan untuk pembubaran Ormas yang berbasis Syiah, karena untuk membubarkan dan melarang organsiasi dan gerakan Syiah sesungguhnya sudah ada payung hukumnya yakni antara lain UU Ormas no 17 tahun 2013 dan KUHP, tinggal ada komitmen dan political will untuk menegakkannya.

Jadi, jika harus diterbitkan peraturan pembubaran ormas lagi, Perppu ini nampaknya tidak ditujukan bagi ormas yang cenderung anarkis dan premanisme (yang jelasjelas bukan ormas yang menjalankan amar makruf nahi munkar).Sebab faktanya, ormas yang demikian ini patut diduga kuat justru "dilindungi" oleh oknum aparat penegak hukum. Perppu ini juga tidak ditujukan bagi ormas yang berbasis keagamaan non Islam, karena justru menurut pandangan subjektif Pemerintah mereka (ormas non Islam) ini seolah pendukung Pancasila dan kebhinekaan, terbukti mereka justru mendukung adanya Perppu ini. ${ }^{6}$

Secara garis besar, adanya Perppu itu disinyalir kuat terjadi karena adanya ormas keagamaan yang dianggap mengganggu stabilitas Negara. Hal ini yang menjadi polemik masyarakat di beberapa daerah di Indonesia. Penolakan-penolakan dilontarkan oleh beberapa kalangan masyarakat baik dari kalangan masyarakat akademis maupun keagamaan.

Sebagian organisasi kemahasiswaan di beberapa kota di Jawa Timur menolak dengan tegas Perppu tersebut. PMII cabang Jember yang mengajak seluruh oraganisasi besar mahasiswa untuk menolak Perppu tersebut. Hal serupa juga dilakukan oleh Forum Komunikasi Ulama Aswaja Jatim, mereka melakukan demontrasi juga di gedung DPRD Jatim. ${ }^{7}$ Di Makasar Sulewesi Selatan, sejumlah masyarakat yang tergabung dalam Aliansi Ummat Islam berkumpul di gedung DPRD Propinsi Sulsel mengadakan unjuk rasa menolak adanya Perppu yang baru dikeluarkan oleh Jokowi itu. ${ }^{8}$ Hal yang serupa juga terjadi di Jawa Barat, Forum Ulama Ukhuwah berunjuk rasa menolak

${ }^{6}$ Asep Warlan Yusuf, Catatan Hukum Perppu Nomor 2 Tahun 2017 https://jurnalislam.com/ catatan-hukum-perppu-nomor-2-tahun-2017/ diakses tanggal 14/08/2017.

7“Tolak Perppu Oramas, Forum Ulama Aswaja Jatim Gelar Aksi” http://www.swamedium. com/2017/08/11/tolak-perppu-ormas-forum-ulama-aswaja-jatim-gelar-aksi/ diakses tanggal $04 / 08 / 2017$

8 "Unjuk Rasa Penolakan Perppu Nomor 2 Tahun 2017 di Kantor DPRD, Polrestabes Maksar Menerjunkan 600 Personel Pengaman" http://tribratanews.polri.go.id/?p=246072 diakses tanggal $06 / 08 / 2017$ 
Perppu. Aksi dilakukan di depan gedung Sate, Jalan Dipenogoro Bandung. ' Bukan hanya terjadi di masyarakat umum atau umum saja, hal serupa juga terjadi di masyarakat elit politik. kelompok yang gencar menolak Perppu terus mengkritik habis langkah Jokowi mengeluarkan Perppu Ormas. Kelompok-kelompok kontra yang dimaksud diantaranya adalah Fadli zon (wakil Ketua DPR Fraksi Gerindra, Fahri Hamzih (Wakil Ketua DRR RI), Busyroh Muqoddas (Mantan Ketua KPK dan banyak lagi yang lainnya. $^{10}$

Situasi yang demikian jika tidak segera ditanggulangi, sangat dikhawatirkan akan menyebabkan kondisi yang carut marut di tengah masyarakat. Masyarakat secara umum akan kebingungan dan pada akhirnya akan mengakibatkan hilangnya trust masyarakat pada pemerintah. Tujuan baik lahirnya Perppu yang semestinya melahirkan hal yang baik pula malah sebaliknya akan menyebabkan kondisi yang negatif di kalangan masyarakat. Masyarakat akan terus-menerus bertikai dalam masalah ini, apalagi bagi ormas yang merasa dirugikan, tentu tidak akan ada rumus taat pada seluruh keputusan pengadilan jika dilandasi aturan tersebut.

Pada situasi dimana masyarakat terpecah dan konflik, sebab adanya situasi prokontra terhadap sebuah aturan-tidak dapat dipungkiri, adanya sesuatu yang dapat mendamaikan dua kubu masyarakat yang bertikai itu, sangat dibutuhkan untuk mengatasi masalah tersebut. Salah satu yang dapat diupayakan adalah memaksimalkan fungsi tokoh agama sebagai mediator dalam menjalin keharmonisan kehidupan sosial kemasyarakatan.

Ikatan tokoh agama dengan masyarakat sangat erat. Hubungan antara tokoh agama dengan masyarakat diikat dengan emosi keagaamaan. Menurut CF. Horikoshi, hubungan tokoh agama dengan masyarakat pada dewasa ini tidak sebatas dalam masalah spiritual keagaamaan saja, tetapi juga sudah mencakup aspek yang lebih luas. Karena itulah, tokoh agama selain berfungsi sebagai peningkat keimanan masyarakat juga berfungsi sebagai mediator perdamaian masyarakat, suksesi kegiatan atau aturan pemerintah dan lain sebagainya. ${ }^{11}$

Problema Perppu Ormas akan mudah terselesaikan, apabila tokoh-tokoh agama ikut serta dalam mencari akar solusi masalahnya. Pada hakekatnya beberapa golongan yang mempermasalahkan Perppu Ormas Nomor 2 tahun 2017 adalah masyarakat yang merasa khawatir akan hak berserikat kelompoknya. Maka sebab itulah, penelitian ini mencoba mengungkap dan menganalisa pendapat tokoh antar agama tentang hak berserikat dalam Perppu tersebut. Kemudian penelitian ini diharapkan dapat dipublikasikan untuk menjadi salah satu landasan masyarakat dalam melaksanakan hak berserikatnya.

\footnotetext{
"“Unjuk Rasa, Massa FUU Jabar Tolak Perppu Ormas" http://www.gemarakyat.id/unjuk-rasamassa-fuu-jabar-tolak-perppu-ormas/ diakase tanggal 107/08/2017

${ }^{10}$ Toni Ervianto, Perppu NO.2/2017 Untuk Kehadiran Negara Agitasi Masalah Bangsa, http://www.swamedium.com/2017/08/11/tolak-perppu-ormas-forum-ulama-aswaja-jatim-gelar-aksi/ diakses tanggal 02/08/2017

${ }^{11}$ Endang Turmudi, Perselingkuhan Kyai dan Kekuasaan,(Yogyakarta: LKiS, 2004) 97
} 


\section{Metode Penelitian}

Penelitian yang akan dilakukan dalam hal ini bersifat penelitian kualitatif dan termasuk jenis penelitian terapan. Penelitian kualitatif ditujukan untuk memahami fenomena-fenomena sosial dari sudut pandang atau perspektif partisipan. Partisipan adalah orang-orang yang diajak berwawancara, diobservasi, diminta memberikan data, pendapat, pemikiran, persepsinya.Pemahaman diperoleh dari melalui analisis berbagai keterkaitan dari partisipan dan melalui penguraian "pemaknaan partisipan" tentang situasisituasi dan peristiwa-peristiwa.Pemaknaan partisipan meliputi perasaan, keyakinan, ideide, pemikiran dan kegiatan dari partisipan. ${ }^{12}$

Jenis penelitian yang berbentuk terapan ini merupakan bentuk penelitian deskriptif yang menggambarkan sebuah tinjauan terhadap masalah yang ada di masyarakat. ${ }^{13}$ Dalam studi ini peneliti meninjau pendapat-pendapat tokoh antar agama terhadap hak berserikat dalam Perpu Nomor 2 Tahun 2017.

Penelitian ini dilakukan di kabupaten Probolinggo, sebab Probolinggo merupakan salah satu kota di Jawa Timur yang dihuni oleh masyarakat multi agama yang hidup dengan rukun. Adanya kerukunan antar ummat beragama di kota tersebut, tentu tidak lepas fungsi tokoh dari masing-masing agama yang mampu menjadi mediator perdamaian. Dari hal tersebut, penulis mengharapkan dapat menemukan pandangan yang universal tentang hak berserikat, khususnya dalam adanya Perppu Ormas,sehingga peneliti memutuskan untuk mengambil judul "Persepsi Tokoh Lintas Agama Kabupaten Probolinggo Terhadap Perppu UU Nomor 2 Tahun 2017 Tentang Hak Berserikat”.

\section{Pembahasan}

\section{Hak Berserikat Dalam UU Nomer 2 Tahun 2017 Persepsi Tokoh Agama Kris- ten}

Adanya perppu Nomer 2 Tahun 2017 oleh tokoh agama Kristen tidak dipahami sebagai sesuatu yang mengancam dan mengukung hak berserikat. Jika dirasa demi kemajuan dan keutuhan bangsa ini, lahirnya Perppu tersebut penting untuk didukung. Ungkapan ini salah satu dikatakan oleh Olga, Pengurus GDPI Gending Kabupaten Probolinggo. Ia mengatakan,

"Kita selaku ummat keristiani dalam bergenagara selalu mempercayakan kepada pibak yang berwenang. jika itu demi kemajuan bangsa kenapa tidak? Toh selama ini kita selaku ummat kristiani meskipun bisa dikatakan minoritas, tapi kita kan temasuk agama yang diakui oleh Negara maka dengan landasan itu kita tidak merasa terancam dengan Perpuu tersebut. ${ }^{14}$

Ummat Kristen tidak mengnggap adanya Perppu tersebut sebagai sebuah ancama bagi kebebesan hak berserikat. Pada konteks ini sangat nampak sekalai bahwa tokoh

12.Nana Syodih Sukmadinata, Pengembangan Kurikulum Teori Dan Praktek, (Bandung: PT Remaja Rosdakarya, 2007) 94.

13. Nana Syodih Sukmadinata, Pengembangan Kurikulum Teori Dan Praktek, 79.

${ }^{14}$ Wawancara, Olga Pengurus GDPI Kabupaten Probolinggo Tanggal 14/09/2018 
Al-`adalah, Volume 22 Nomor 1 April 2019

agama Kristen sama sekali tidak dibatasi akan hak berserikatnya di Negeri ini.

Ada hal yang terpenting dalam menilai apakah Perppu tersebut melanggar hak berserikat atau tidak? Hal tersebut ada hal dasar yang paling dasar dan menjadi pokok pikiran utama dalam pembuatan aturan, yakni tidak menabrak isi dan amanah Pancasila. Ia menambahkan,

Selama hal itu tidak menabrak pancasila menurut saya sib sab-sab saja ya mas, apalagi jikea berpotensi untuk memecah belah bangsa, saya sangat sepakat jika pemerintah mengambil langkah tegas tersebut, contohnya saja HTI yang dinilai pemerintah sebagai organisasi yang makarlah ya istilabnya karena ingin mengganti pancasila dengan dasar lain, dan itu menurut saya bagus demi menjaga NKRI ini. ${ }^{15}$

Hal yang penting yang terkandung dalam Pancasila bisa diamalkan, tidak akan ada aturan negara yang dianggap melanggar hak. Yang terpenting adanya sebuah komitmen dalam menjalankan aturan tersebut, yakni komtmen terhadap pegamalan Pancasila. Hal ini sebenarnya yang akan menjadi masalah jika tidak dilakukan. Banyak orang yang tidak paham pada apa yang diamanah falsafah negara ini. Hugo Sutisno, mengatakan

Sebetulnya kan kitanya saja yang kurang memahami pancasila seutubnya, namun jika kita memahami pancasila dengan baik dan memiliki I'tikad untuk menjalani hidup seperti apa yang terkandung dalam sila-silanya tentu ketimpangan yang ada sekarang tidak akan pernah terjadi, namun kan masalahnya lagi-lagi kita masib dangkal dalam memahami pancasila dan belum bisa menerapkan pancasila dalam kehidupan kita, terutama dalam berbangsa dan bernegara. ${ }^{16}$

Ada yung paling fundamental yang menjadi dasar sebuah aturan di negeri ini dirumuskan. Yang demikian tersebut adalah nilai-nila Pancasila. Pancasila merupakan ruh moral yang sesuai dengan ajaran agama manapun termasuk agama Kristen. Pancasila mengajari moralitas sosial pada semua rakyat Indonesia. Jika ajaran tersebut dapat masuk ke seluruh aspek baik aturan maupun pengamalannya, tidak akan ada pelanggaran hak di kehidupan berbangsa dan bernegara.

Ini yang kemudian menjadi alasan Perppu No 2 tahun 2017 ini tidak melanggar hak berserikat rakyat. Sebab aturan tersebut masih berlandaskan pada ajaran moral berbangsa dan bernegara sebagaimana yang diamanahkan Pancasila. Aturan tersebut selama tidak diselewengkan dalam aplikasinya tentu tidak akan melanggar hak rakyat bangsa ini.

Berdasarkan hal ini, menjadi jelas bahwa Perppu ini bisa melanggar hal berserikat rakyat sebab melanggar tanggung jawab dari sila-sila yang ada dalam Pancasila. Pada sisi ini, yang penting sebenarnya adalah pengamalan tidak berlawananan dengan sila-sila yang ada. Misalnya dalam praktenya aturan tersebut merusak peratuan bangsa dan rakyat, tentu jika terjadi demikian Perppu tersebut tidak akan memiliki ruh nilai dasar yang semestinya diperjuangkan. Hugo mengatakan,

${ }^{15}$ Wawancara, Olga Pengurus GDPI Kabupaten Probolinggo Tanggal 14/09/2018

${ }^{16}$ Wawancara, Hugo Sutisno Pengurus GKA Kabupaten Probolinggo Tanggal 14/09/2018 
M. Saiful Anam, Abd. Rozzaq, Persepsi Tokoh Lintas Agama...

Yang lebih penting sebetulnya kita saling menghormatilah dan saling menjaga saja antar sesama jadi tidak akan ada pertikaian antar ummat beragama selama kita masih tetap menghormati dan saling menghargai. Apalagi orang gending sini kan sudah bisa dikatakan agak maju ya, tidak terlalu mempersoalkan masalah agama, jadi kita enak dan rukun dalam bermasyarakat. $^{17}$

Secara garis besar, beberapa ummat Kristen sebenarnya apatis pada perseloan aturan ormas yang ada tersebut. Hal ini sangat nampak sekali, dari beberapa pihak yang sempat diwawancarai. Kurang mengerti alasan yuridis lahirnya aturan oramas tersebut. Paparannya hanya garis besar saja, seperti perkataan "yang penting tidak melanggar UUD”, "demokratis" dan sebagainya.

Saat ditanya bagaimana pendapatnya jika hadirnya aturan ini dihubungkan denga ada masalah kondisi yang darurat. Mereka menyepakati hal tersebut. Menurutnya hari ini banyak organisasi yang bukan hanya ingin menyampaikan pendapak, akan tetapi menggangu ketertiban umum. Yang demikian ini tentu perlu diatur. Ada hak yang harus dihargai juga, dalam menegakkan hak. Misalnya-menurut Yusak-berserikat dalam hal melakukan kejahatan pada orang lain. Berserikat merupakan hak tetapi kejahatan pada orang lain tentu merupakan pelanggarna hak. Sama dengan persoalan pada aturan ini. Aturan ini tentu dianggap melanggar hak. Akan tetepi perlu juga dilihat berapa yang berpotensi dijaga dalam hadirnya aturan No 2 Tahun 2017 ini. $^{18}$

Hak beserikat merupakan hak sosial. Hak sosial berfungsi untuk menjaga dan mempermudah tegapainya hal personal. Jadi hak berserikat bebas digunakan apabila tidak tetap pada orientasinya, yakni menjamin tergapain pemenuhan hak personal seperti berbicara, hidup bahagia dan sebagainya. Jadi hak berserikat secara otomatis tidak boleh diperjuangkan apabila berlawan dengan penggapain hak personal.

Berdasarkan hal ini maka, kondisi dikatakan apabila hak personal banyak dilanggar. Negera yang mempunyai kewenangan konsensus tertinggi memang sesegera mungkin bertindak pada kondisi yang demikian ini. Artinya, mempertimbangkan dengan mengarahkan lagi agar hak berserikat itu menjadi tetap berorientasi pada terpenuhnya hak personal.

Pada sisi ini, Olaga mengatakan bahwa lahirnya undang-undang ini begitu sangat diharapkan dewasa ini. Beberapa tahun akhir-akhir ini, semua sudah paham. Ada beberapa organisasi keagamaan yang sering memecah belah negeri. Bukan hanya terjadi di negeri Indonesia. Beberapa negera banyak banyak yang diancam pertiakaian antar golongan rakyat sendiri.

Ada juga ormas yang sering melakukan intimidasi pada rakyat. Melakukan tindakan radikal separatis. Ini tentu sangat menggagu ketentraman dan semakin membuat jarak pada sampainya kehidupan yang sejahtera. Maksudnya, kegiatan yang dilakukan

17 Wawancara, Hugo Sutisno Pengurus GKA Kabupaten Probolinggo Tanggal 14/09/2018

18 Wawancara, Patria Yusak Kepala GKJW Kabupaten Probolinggo Tanggal 2/10/2018 
malah melanggar hak personal dari masing-masing rakyat. ${ }^{19}$ Yang demikian ini tentu perlu diatur, agar ormasi yang ada di negeri ini searah dan tidak menghianati konstitusi negara ini.

Berdasarkan hal ini, nampak beberapa pihak gereja merasa sangat sepakat hadirnya undang-undang ini. Berdasarkan penjelasan-penjelasasan di atas. Nampak ditemukan bahwa hak berserikat dalam undang-undang itu adalah pengaturan hak sosial. Seperti apa yang dijelaskan oleh David Hallenbech, hak sosial hari mengawangi hak personal. Dari itu sebuah atur perlu diputuskan guna memberikan arah yang baik dalam penjaminan hak personal. Hal inilah yang mendasari sebuah aturan harus dalam mengatur dan menjembatani adanya hak sosial ini.

Guna penjelasan yang sederhana terkait hal ini adalah seabagaimana tergambar dalam tabel di bawah ini,

Gambar Hak Berserikat dalam UU No 2 tahun 2017 tentan Organisasi Kemasyarakatan dalam perspektif tokoh agama kristen

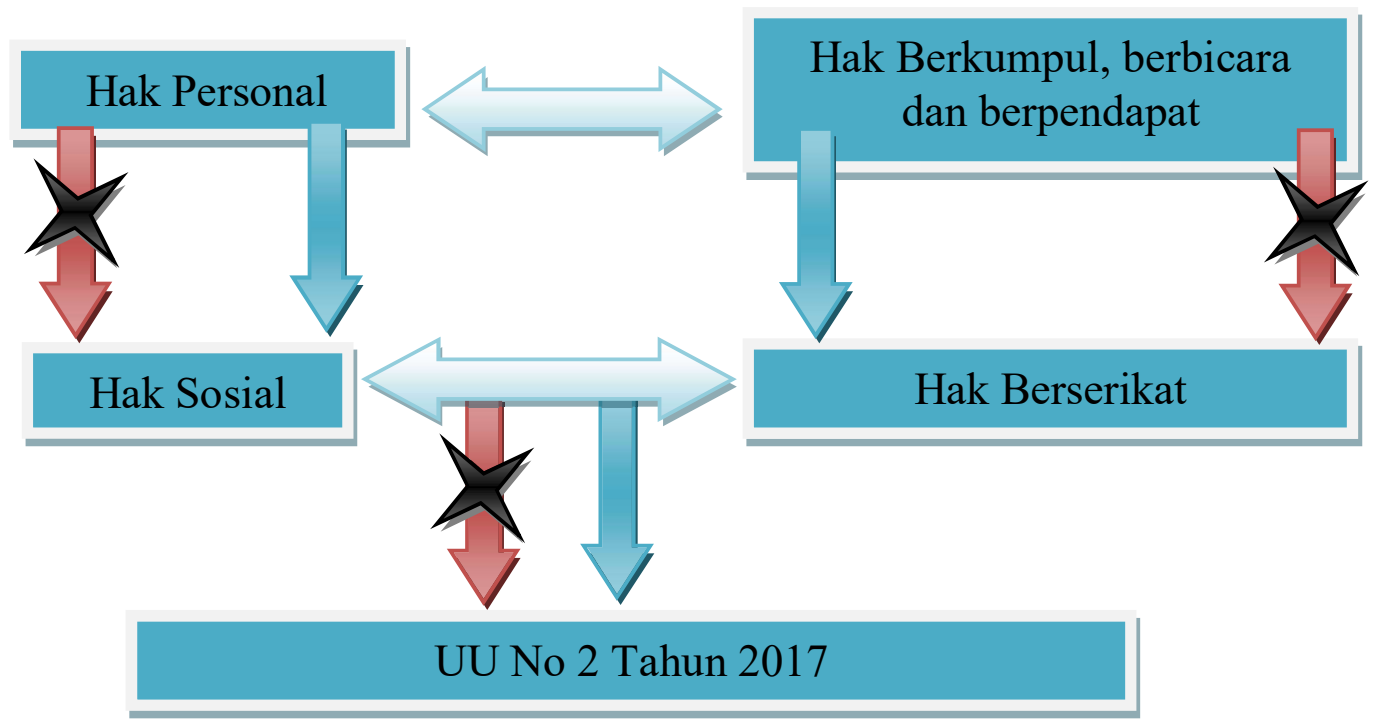

\section{Hak Berserikat Dalam UU Nomer 2 Tahun 2017 Persepsi Tokoh Agama Islam}

Polemik aturan Perppu Nomer 2 Tahun 2017 sudah didengar oleh beberapa tokoh Islam kabupaten Probolinggo. Ada hal beberapa yang mereka sampaikan terkait dengan hak berserikat dalam Perppu tersebut. Salah satu penjelasan beberapa tokoh yang diwawancarai menggambarkan bahwa adanya kepercayaan bahwa Perppu tersebut lahir karena paham radikal dewasa ini berkembang di kehipuan sosial politik bangsa ini.

KH Abdusshomad menjelaskan bahwa ummat Islam Indonesia sebanarnya merasa sangat diuntungkan lahirnya undang-undang tersebut. Hal ini disebabkan beberapa tokoh Islam di Nusantrara ini bahkan sejumlah tokoh ulama merasa khawatir pada ali-

${ }^{19}$ Wawancara, Olga Pengurus GDPI Kabupaten Probolinggo Tanggal 14/09/2018 
ran-alitan ormas keagamaan yang akhir-akhir ini meresahkan kerukanan dan ketentraman kehidupan berbangsa dan beragama ini. Ia mengatakan,

Aliran keras agama yang tidak toleran sungguh penyebarannya begitu massif dan cepat. Ajaran non tolerans yang berdasarkan agama sangat mengancam kerukunan kita sebagai bangsa yang homogen, Sebab hal ini kemudian perlu adanya cara cepat juga memahami gerakan tersebut. Pada sisi inilah sangat disyukuri jika ada aturan mampu mempermudah dan cepat penyelesain masalah ini. ${ }^{20}$

Perppu No 2 tahun 2017 dianggap sebagai aturan yang mampu mendorong gerak cepat pengamanan dan penjagaan ideologi bangsa yang diamanahkan oleh Pancasila. Pancasila sebagai dasar nilai kerukunan tentu harus dijaga. Pada konteks inilah, dukungan beberapa tokoh agama menjadi penting untuk mengawal peraturan yang membawa ruh amana falsafah bangsa.

Menurut Abdul Halim, Perppu yang dikeluarkan pada tahun 2017 ini adalah perppu yang diharapkan dapat memaksimalkan upaya pemberantasan ajaran untolerans di masyarakat. Dari orientasinya sebenaranya sanag jelas bahwa Perppu tersebut dapat membuat sistem yang lebih tanggap pada ancaman fundamentalis ormas, tanpa memberangus hak asasi berserikat rakyat.

Memang, menurutnya pada satu sisi Perppu tersebut memberangus hak berserikat. Tetapi hal demikian sebenarnya hanya untuk perserikatan yang berdampak negative pada penerapan amanah yang ada dalam Pancasila. Dengan kata lain, hak diperuntukkan pada ormas yang menyebabkan kerasahan dirusaknya keamanan dan ketertiban kehidupan berbangsa dan beragama.

Menurut Abdul Halim, ini sebenarnya sama hal dengan Islam. Islam mencemoh persekutuan yang orientasinya pada pengrusakan nilai-nilai kemanusian dan ajaran moralitas agama. Ia menjelaskan bahwa perserikatan yang menjunjung tinggi kemanusian tidak akan pernah dirusak karena adanya aturan ini. Islam juga demikian, perserikatan yang dimaksud dalam agama Islam adalah semangat kebersamaan dalam hal kebaikan. Islam juga melarang perserikatan yang ditujukan untuk memperlemah rasa kasih sayang dalam pergaulan kehidupan sosial manusia. Abdul Halim mengatakan,

Keberserikatan dalam beberapa literatur ajaran Islam dikemukan sebagai jasadil wabid. Maksudnya adanya saling mengasibi, saling menyaying dan saling menolong sesama manusia. Ada juga yang mengibaratkan berserikat ini sebagai satu bangunan yang saling menopang. Artinya, semangat berserikat dalam agama Islam harus membawa nilai persatuan dan saling welas asih anat sesame manusia. Tentu ajaran ini begitu senada kan dengan apa yang ada dalam Perppu tersebut. ${ }^{21}$

Terkait dengan proses aturanya sebagaimana hal yang paling signifikan untuk diperhatikan adalah terkait dengan kondisi darurat yang dimaksud dalam usulan aturan

20 Wawancara, KH Abdusshomad Bukhori Ketua MUI Kabupaten Probolinggo Tanggal $14 / 09 / 2018$

${ }^{21}$ Wawancara, Abdul Halim Ketua FKUB Kabupaten Probolinggo Tanggal 14/09/2018 
ini. Kondisi darurat dalam agama Islam dipahami sebagai hal yang dapat memberikan disepensasi hukum wajib menjadi tidak wajib. Pada kondisi tertentu, barang yang najis bisa jadi halal disebabkan kondisi darurat. ${ }^{22}$

Begitupun negara konstalasi kenegaraan ini. Hak beseraikat memang merupakan hal yang wajib dijaga tanpa terkecuali bagi siapapun. Pada kondisi tertentu, yang demikian dapat tidak dibebaskan apabila berkenaan dengan kondisi darurat. Jika demikian maka memeng perlu adanya aturan pada kondisi darurat. Pada sektor inilah untuk menjaga kemafasidan perlu dirumuskan sebuah aturan yang mengatur kondisi ini.

Selain ajaran Agama Islam terkait dengan perserikat memang sudah diatur. Islam agama yang juga mengatur hal-hal yang demikian ini. Orang muslim memiliki acauan nilai dan dasar dalam melakukan sebuah perseriakatan. Artinya, aturan Islam memberiakan standar hukum hal berserikat. Bahkan bukan hanya hukum, akan tetapi juga nilai.

Adapun nilai atau dasar yang tidak boleh dilanggara dalam Islam, adalah sikap nilai teologinya. Menurut Abdushomad, berserikat dalam Islam harus berdasarkan nilai ilahiyah dan moralitas agama. ${ }^{23}$ Artinya, harus berdasarkan aturan yang ada dalam hadist dan sunnah nabi. Hal ini sebagaimana yang diungkapkan oleh Al-Qurthubi dalam kitabnya al Jami' Li Abkamil Qur'an. Dalam kitab tafsir al-Qur’annya, dia menjelaskan bahwa anjuran berserikat itu harus berlandaskan pada KitabNya dan Sunnah Nabinya. ${ }^{24}$

Begitupun dengan UU tentang ormas ini. Aturan ini tentu merupakan aturn kenegaraan. Hak berserikat diatur agar sesuai dengan landasan negara ini, sama dengan Islam yang harus sesuai dengan landasan utama ajarannnya. Jadi tidak salah, jika negara ini mengatur hak berserikat untuk sesuai dengan aturan dasarnya. Waktunya sangat tepat melihata masalah negara yang terjadi dewasa ini, Sebagaiman penjelasan Abdul Halim yang mengatakan,

Menurut saya, secara politik tepat waketu. Dengan banyaknya organisasi yang berorientasi pada radikalisme dan kekerasan, semakin banyak orang percaya pada khilafah. Jika ideologi khilafah, pancasila kita otomatis gugur. Aturan akan diskriminatif agaman non Islam. Kita sebagai negara yang multiras, agama dan etinis, harus harmoni kehidupan sosial kita yang sudah terjalin sejak awal. ${ }^{25}$

Jika melihat gejolak sosial yang ada saat ini dari hasil suver Peneliti Pusat

${ }^{22}$ Kondisi darurat dalam hukum islam yang dimaksud sebagaimana yang dikatakan Al-Jurjani di dalam karyanya al-ta'rifat, mengatakan, kata dharurat itu dibentuk dari al-dharar (mudarat), yaitu suatu musibah yang tidak dapat dihindari. Said Agil Husain al-Munawar, Konsep Darurat Dalam Hukum Islam : Studi Banding Dengan Hukum Positif, ( Jakarta : Gaya Media Pratama,1997)71

${ }^{23}$ Wawancara, KH Abdushomad, tanggal 12/12/2018

${ }^{24} \mathrm{Hal}$ ini dijelaskan saat menjelaskan tafsir QS. Al Imron ayat103. Lengkapnya lihat. Abi Abdillah Muhammad al-Qurțubi, al-Jamì' li A hkaam al-Qur'an. (Beirut : Muassasah al-Risālah, 2006), hal. 164.

${ }^{25}$ Wawancara, KH Abdushomad, tanggal 12/12/2018 
Pengkajian Islam dan Masyarakat Universitas Islam Negeri (PPIM-UIN) Jakarta, bisa ditafsirkan adanya situasi kegentingan yang memaksa sebagai dasar penerbitan Perppu. Adanya aksi teror dan orang-orang yang menyatakan dukungannya terhadap ISIS, merupakan akibat dari maraknya ormas-ormas radikal.

Begitupun sebagiaman publis Surveinya Saiful Mujani Research and Consulting (SMRC) menyebutkan, ada 9,2 persen responden yang setuju NKRI diganti menjadi negara khilafah atau negara Islam. Pemerintah juga berhak menafsirkan faktor kegentingan yang memaksa secara sepihak.

Di sisi lain, ormas yang dibubarkan memiliki kesempatan untuk menggugat keputusan pemerintah melalui pengadilan. "Pemerintah berhak menafsirkan faktor genting. Hasil survei SMRC, yakni 9 persen responden setuju khilafah. Memang kecil, tapi dari ukuran jumlah penduduk, maka sekitar 10 sampai 15 juta orang yang berpandangan seperti itu. Dari sisi hukum, penerbitan aturan oramas merupakan langkah hukum yang demokratis dalam menata keberadaan ormas. Melalui penerbitan aturan tersebut, pemerintah tidak bisa sewenang-wenang memberangus kebebasan berserikat. Perppu sebagai proses hukum merupakan jalan demokratis menuju penataan organisasi. Agak naif jika sebuah rezim bisa dengan mudah memberangus kebebasan berserikat dengan sangat mudah. ${ }^{26}$

Adapun berdasarkan penjelasan Agus Zainuddin, salah satu pengurus FKUM Probolinggo, menjelaskan bahwa aturan ormas syah. Menurutnya sedikinya ada tiga alasan fundemental yang logis aturan ini lahir. Pertama, Penetapan PERPPU tersebut sebagai langkah antisipasi dari Pemerintah Dalam rangka menjaga keutuhan NKRI yang telah terbukti menjadi jalan terbaik untuk menjaga keberlangsungan kehidupan agama, bangsa dan negara Republik Indonesia. Kedua, Penyebaran paham radikalisme di Indonesia berlangsung sangat masif dan terstruktur. Ketiga, Pemerintah menilai PERPPU ini dibuat semata untuk melindungi ideologi kebangsaan, bukan untuk memberi batas kebebasan berdemokrasi. ${ }^{27}$

Berdasarkan penjelasan di atas, dapat ditarik konklusi bahwa tokoh ummat Islam di kabupaten Probolinggo, secara penuh mendukung perubahan atas UU oramas. Hal demikian ini dikarena beberapa alasan hukum terkait kondisi darurat yang terjadi. Selain itu, tentang hak berserikat dalam Islam memang perlu diatur. Tuhan mengatur dan memberikan ukaran hak berserikat. Tidak bebas secara mutlak.

\section{Kesimpulan}

Menurut Tokoh kristiani, hak berserikat merupakan hak sosial manusia, bukan hak personal dan juga bukan hal instrumental. Apabila hak sosial ini dihormati dan dijaga, tentu hak personal juga akan terjaga. Hak sosial menjadi hal penting dalam penjaminan hak personal seseorang. Hak berserikat yang merupakan hal sosial merupakan penjaminan bagi hak personal berupa kebebesan berpikir dan berpendapat. Berserikat

\footnotetext{
${ }^{26}$ Wawancara, Abdul Halim Ketua FKUB Kabupaten Probolinggo Tanggal 14/09/2018

${ }^{27}$ Wawancara Agus Zainuddin (Pengurus FKUB Probolinggo0 tanggal 21/12/2018
} 
artinya berkelompok, berpikir bersama dan mengemukakan pendapat. Terjamin hak berserikat akan juga dapat menjamin hak personal ini. Jika hak berserikat dihilangkan, maka tidak akan ada kesempatan bagi setiap personal untuk berkumpul dan menyatakan pendapatnya.

Sedangkan menurut tokoh Muslim, hak berserikat dalam agama Islam bukan terkait dengan hak saja. Akan tetapi, juga merupakan kewajiban yang harus dilaksanakan oleh seliuruh ummat. Berserikat bukan hanya nikmat dari Tuhan, tetapi juga kewajiban. Bersekutu merupakan anti tesa dri berpecah belah atau bertikai. Dalam Islam sendiri berpecah belah adalah sangat dilarang. Seluruh muslim harus memiliki semangat persatuan atau berserikat dalam hal yang baik. Hal yang demikian ini jelas tergambar dalam kitab suci ummat Islam.

Tokoh ummat Islam di kabupaten Probolinggo, secara penuh mendukung perubahan atas UU oramas. Hal demikian ini dikarena beberapa alasan hukum terkait kondisi darurat yang terjadi. Selain itu, tentang hak berserikat dalam Islam memang perlu diatur. Tuhan mengatur dan memberikan ukaran hak berserikat. Tidak bebas secara mutlak.

Sedangkan menurut tokoh krisitiani, Hak beserikat merupakan hak sosial. Hak sosial berfungsi untuk menjaga dan mempermudah tegapainya hal personal. Jadi hak berserikat bebas digunakan apabila tidak tetap pada orientasinya, yakni menjamin tergapainnya pemenuhan hak personal seperti berbicara, hidup bahagia dan sebagainya. Jadi hak berserikat secara otomatis tidak boleh diperjuangkan apabila berlawan dengan penggapain hak personal. Dasar inilah yang kemudian melandasi sebuah padanngan UU No 2 Tahun 2017 disepakati diresmikan.

\section{Daftar Pustaka}

al-Munawar, Said Agil Husain. Konsep Darurat Dalam Hukum Islam : Studi Banding Dengan Hukum Positif, (Jakarta : Gaya Media Pratama. 1997)

Jimly Asshidiqie, Kemerdekaan Berserikat, Pembubaran Partai Politik dan Mabkamah Konstitusi, Sekretariat Jenderal dan Kepaniteraan Mabkamah konstitusi, Jakarta:Konstitusi Pers, 2005)

Sekertaris Negara, Undang-Undang Dasar Negara Republik Indonesia Nomor 39 Tahun 1999 tentang Hak Asasi Manusia

Jimly Asshiddiqie, Mengatur Kebebasan Berserikat Dalam Undang-Undang, bttp://jimlyschool.com/read/analisis/274/mengatur-kebebasanberserikat-dalam undangundangterakhir diakses tanggal 12-05-2017.

Endang Turmudi, Perselingkuhan Kyai dan Kekuasaan,(Yogyakarta: LKiS, 2004)

Nana Syodih Sukmadinata, Pengembangan Kurikulum Teori Dan Praktek, (Bandung: PT Remaja Rosdakarya, 2007)

Said Agil Husain al-Munawar, Konsep Darurat Dalam Hukum Islam : Studi Banding Dengan Hukum Positif, ( Jakarta: Gaya Media Pratama,1997)

Abi Abdillah Muhammad al-Qurțubi, al-Jamī li Abkām al-Qur'an. (Beirut : Muassasah 
al-Risālah, 2006)

Asshiddiqie, Jimly.2006. Hukum Tata Negara dan Pilar-Pilar Demokrasi; Serpihan Pemikiran Hukum, Media, dan HAM, (Jakarta; Konstitusi Press. 2006)

Indonesia, Undang-Undang Nomor 12 Tahun 2005 tentang Pengesahan International Covenant on Civil and Political Rights (Konvenan Internasiona tentang Hak Sipil dan Politik), LN Tahun 2005 Nomor 119, TLN Nomor 4558.

Monib, Mohammad \& Islah Bahrawi. Islam dan Hak Asasi Manusia dalam Pandangan Nurcholish Madjid, (Jakarta: Gremedia Pustaka Utama, 2011)

Turmudi, Endang. Perselingkuhan Kyai dan Kekuasaan,(Yogyakarta: LKiS., 2004)

Yuliandri. Asas-Asas Pembentukan Peraturan Perundang-Undangan Yang Baik, (Jakarta, PT. Rajagrafindo Persada. 2009) 